\title{
The arena of multiinterest, governance and fraud - A critical review of BC bailout
} \author{
Efferin $^{b}$, Yenny Tjiamudjajac \\ aFaculty of Economic and Business, University of Sebelas Maret (UNS). Surakarta. \\ bFaculty of Business and Economic, University of Surabaya (UBAYA) Surabaya \\ cEditor, translator \\ ${ }^{*}$ Corresponding author's email:ruddytri@gmail.com
}

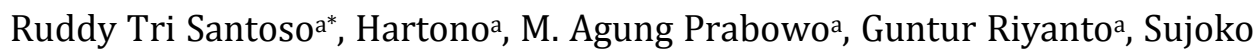

\section{H I G H L I G H T S:}

1. PT. Bank Century's default in the end of 2008 was influenced internally by frauds and non-corporate governance, and externally by the global financial crisis.

2. The government of Indonesia believed that BC should be bailed out because if it was closed, it would have caused systemic impact to the entire Indonesian economy.

3. The crucial timing gave chances to the multi interests of bankers, politicians, and regulators to create a situation that politically constituted the bailout.

4. The judgement of systemic impact criteria and the decision to bail out neglected some prudential aspects.

5. The major reason of bail out was that the bank was too politically significant to fail.

\section{Article History \\ ABSTRACT}

Received: 18-05-2014

Revised receipt: 28-05-20014

Accepted: 03-06-2014

Available online: 05-06-2014

Keywords:

Bank bailout;

Governance;

Fraud.

The bailout of PT. Bank Century (BC) at the end of 2008 ignites many debates. If the Indonesian Central Bank had not bailed it out, would it have been a systemic disaster for Indonesian economic? BC's total assets were not significant to the national banking asset. Why was it so important to bail BC out? This research wants to find answers to the following questions: 1) considering the internal problems of BC since 2005, was it worth to bail it out, and was the amount paid appropriate? 2) How bad was the internal problem in consideration of corporate governance theory, fraud theory, and in accordance with prudential banking principals? 3) Was the decision to bail out relevant for the national banking stabilization? 4) Was the failure of BC in 2008 a symptom of market failure, or a governance failure of $\mathrm{BC}$ and a regulation failure of the Indonesian Central Bank? This research uses descriptive qualitative method by in-depth analysis. The qualitative variables are classified to some significant factors which influence the decision to bail out. The result of this research shows that the historical performance, the corporate government and the fraud of the bank were not appropriately reviewed before the government decided to bail BC out. Even though the bailout was able to keep the national banking stabile at that time, the judgment of the decision was not purely economic. The non-economic factor was that the bank was too politically significant to fail.

JEL Classification:

G34; G38; J33.

DOI: http://dx.doi.org/10.18533/jefs.v2i02.137

(C) 2014 The Authors. This is an open access article under the terms of the Creative Commons Attribution License 4.0, which allows use, distribution and reproduction in any medium, provided the original work is properly cited.

\subsection{Introduction}

A bail out is an act to save a default bank by taking over $100 \%$ shares of the bank. The default can be caused by various reasons such as; an imprudent banking, a market failure, or a psychologically affected market. The 
important reason of a bail out is to redeem market volatility. Market volatility is dangerous because it may cause a bank rush, which in turn creates domino effect to the whole banking institution and makes the national economic instable.

BC was founded from a merger of three banks at December $6^{\text {th }}, 2004$. The banks were PT. Bank CIC International, PT. Bank Pikko, and PT. Bank Danpac. Historically, PT. Bank CIC had some fictional and high-risk transactions. The amount was up to US\$25Billion. Regulation requires the bank to accumulate PPAP (Penyisihan Penghapusan Aktiva Produktif/Reserve for Loans Losses), which in turn results in a negative Capital Adequacy Ratio (CAR). Bank Pikko contained Texmaco's bad debt, which was changed to Dresdner Bank Medium Term Notes (MTN). The low quality of the MTN required the bank to accumulate a big amount of provisions in loan losses. This in turn also results in a negative Capital Adequacy Ratio (CAR). Danpac is a healthy and prudential bank. An Indonesian Central Bank report dated on October 31, 2005 shows that the CAR of BC on February 28, 2005 (two months after merger) was negative $132.5 \%$. Due to regulations, after this report the bank should be put under special surveillance. In fact the bank was normally operating until the end of 2008 until BC failed to pay a withdrawal of a USD 1 Billion deposit. The rumor of bankruptcy ignited bank rush, and it finally caused a major liquidity crisis to the bank. The government marked PT Bank Century as a systemic risk bank which means that it should not be closed at any cost. The government put in some temporary equity to bail it out. In the end the bailout cost as much as USD 6, 7 Billion.

Researches about bank bailouts were conducted before, but it emphasized rather on bank failures caused by nonprudential conduct in normal situations. Former researches do not consider any financial crisis or the Indonesian context. This research is unique because it reviews a bank bailout in a global financial crisis and that BC was the only bank to undergo a liquidity crisis, which needed an intervention of the Indonesian government. Experts have debated over questions such as whether or not the global financial crisis affected the Indonesian economy, and did PT Bank Century really have systemic impact to the Indonesian economy, and was it appropriate to spend USD 6.7 billion to save the bank. Long before the bank was formed it already had problems which naturally climaxed when the global financial crisis happened. The quantitative data of BC shows that its internal condition was not good or systemically significant to the Indonesian economy, yet it was rescued no matter what. We come to consider that the political condition of Indonesia as the major reason of the bailout after conducted some interviews with some key persons.

This research will: a) review the financial performance of $\mathrm{BC}, \mathrm{b}$ ) review the financial performance ratio of $\mathrm{BC}$ by various financial theories to explain its condition, c) quantitatively and qualitatively analyze the application of corporate governance and fraud theory on BC. d) Use a descriptive qualitative method of the related factors and/or actors, to analyze the facts and extracted the conclusions

The case of $\mathrm{BC}$ is chosen because it is a national issue in Indonesian banking. The scale and complexity of the case are massive and logical. The case can be accessed by available sources, within a certain time limit. These considerations make the case both worthy and feasible to be observed.

\subsection{Literature review}

Former researches about the systemic impact of bank performance are using traditional financial theory. Those researches analyze bank performance from a fundamental aspect. The fundamental condition can be seen in financial reports and its ratios such as liquidity, rent ability, and solvability. Bad indicators in the financial report may mean that losses and bankruptcy is inevitable. Kaufman (1996) states that a bank bankruptcy is in fact as common as any other bankruptcy. They are caused by non-prudential regulations, inefficiency and contra productivity. Davis (1992) argues that people are more afraid of financial and banking systemic risks, than of other sectors such as automotive or real estate, because the intangible situations are more difficult to predict. Mark Flannery (1995) has a similar argumentation as Davis, bank bankruptcy costs are higher so that the banking business is unique, and it always needs financial assistance because it includes social aspect and the politic of this business is sensitive to conflict. These factors require the prudential principles of the banking industry. In the case of $\mathrm{BC}$, the bank was bail out even though its fundamental data shows that the bank has had financial problem since it was founded on December 2004.

Another consideration to bail BC out was that the government believed the bank has a systematic risk to Indonesian economy. Regarding the criteria of systemically important bank (SIB), Slovick (2012) proposes a theory of systemically important bank based on the calculation of equity structure. Some banks are systemically important if they have $70 \%$ of the total assets of the banking industry in the country, calculated by weighted average of its asset to the national banking total asset. Consequently the SIBs will also have $70 \%$ of the total equity in that banking industry. In Indonesia the total number of systemically important banks consists of 15 banks, including private ones and government ones. These are: Mandiri, BRI, BCA, BNI, Danamon, CIMB Niaga, BII, Panin, Permata, BTN, OCBC 
NISP, Bukopin, Mega, BTPN, and UOB Indonesia. Again, according to this theory BC was not a systematically important bank.

Research gaps emerge because classical assumption tests through the financial performance theory and the systemically important bank theory do not meet. To explain this phenomenon this research uses behavior finance theory, corporate governance, and fraud theory. Considering the impact of global crisis, BC was a bank with a systemic impact. The economic crisis in 2008-2009 was defined as an economic recession because it was short term. Brut to Domestic Product declines for six months in a row. The signs of recession are an increasing unemployment level, a stagnant salary level, and declining retail sales. The World Bank and ASEAN secretary in 2009 claimed that the global economic crisis in 2008-2009 caused a declining income per capita in countries throughout the world. This abnormal situation also explained by Widoatmodjo (2010), he researched about the systemic impact of BC by probit and logit regression to test investor behavior in BEI (Bursa Efek Indonesia) in the end of 2008. He finds that at that time, investors did not behave rationally. Negative sentiment in the market could be a dominant factor for the society to rush a bank if $\mathrm{BC}$ was closed.

Shleifer and Summers (1990) argue that there are two pillars in the behavior finance theory, which influence the investor's decision; limited arbitrage and investor's psychological bias. These two pillars determine buy or sell positions of a rational investor when he senses a mispricing. De Long etal. (1990), continued by Shleifer and Vishny (1997) propose that the risk of a rational investor is the arbitraged share value. That is; noise traders mislead decision when a rational investor should always decide on fundamental data. This distorted attitude happens because of a deviation in the information process and the limited ability to have the right information. Similarly, in the case of $\mathrm{BC}$ the customers of all the banks possibly react because of a deviation in the information process and any negative information can create a bank rush.

Corporate governance is a concept to enhance corporate performance by monitoring management performance and accountability based on a set of rules. Corporate governance builds a structure to aim at certain goals and acts as tools of performance monitoring (Dharmawati, et.al., 2004). Corporate governance will reduce agency costs and also improve corporate image and reputation (Akhtaruddin, Hossain, Hossain, and Yao, 2009). Corporate governance in banking is even more important because of some considerations. First, the bank has a dominant position as an economy growth machine (King and Levine, 1993). Second, in a country with an undeveloped equity market, a bank is the main institution of lending. Third, a bank is the prime institution to national saving mobilization. Fourth, bank liberalization by privatization and economy deregulation gives the bank's manager broader power to operate a bank.

Banking as an institution has a specific nature, which is different from non-financial institutions (Macey and 0'Hara in Supriyatno, 2006). The uniqueness of this nature blends with the situation of the Asian financial crisis; leads this research to corporate governance problems (Arun and Turner in Supriyatno, 2006). The countries with deficiency in practicing corporate governance suffered most in 1997 to 1998 (Husnan, 2001). The application of corporate governance can be seen in the audited financial report of a company. Financial report is a tool for a company to inform about its condition to its stakeholders. This information has to meet quantitative and qualitative standards (fundamental concept of financial report). Information should be focused on the general needs of its stakeholders, not to cater to certain individual benefit. When a financial report is arranged for a certain need and want of a party it will create fraud risks, the report does not inform about the true condition of the company and it causes loss to the other parties. Gravitt (2006) and Nguyen (2008) say that fraud in financial reports has certain schemes: 1.) falsifying, changing, or manipulating financial material facts, supporting documents, or business transactions. 2.) Intentional negligence or misrepresentation of events, transactions, accounts, or other important information.3.) Intentional misuse of accounting principles or procedures to measure, to disclose, and to report economical events and business transactions. 4.) Intentional negligence in disclosure or improper disclosure representation.

To understand how a fraud causes loss, we need to define what fraud is. According to Badan Pemeriksa Keuangan (BPK)-Supreme Audit Board (2008)the definition of fraud is: misinterpretation of past and present, of material facts, made knowingly or recklessly, intended to make a party act, and the party suffers a detriment because of the misinterpretation. ACFE mentions three types of fraud: a) Asset misappropriation: misuse or stealing of a company's assets. This type is tangible and the value of the loss is able to be defined. b) Fraudulent statements: financial arrangements in a financial report to benefit illegally. c) Corruption: included in corruption are conflicts of interest, bribery, illegal gratitude, and economic extortion.

The link between corporate governance and fraud can be explained as follows: a.) Corporate governance includes company culture and authorization delegation, and is designed to eliminate fraud. b.) Transaction level control process by an internal auditor is a control and preventive process to ensure that only legitimate transactions takes place in the system. c.) Retrospective examination by an external auditor is aimed to detect fraud before it becomes big and dangerous for the company. d.) Investigation and remedial by a forensic audit to determine remedial acts related to size or depth of fraud. Tiscini and Donato (2004) propose that relating to CG and fraud in private and 
Government Companies, accounting fraud tends to be caused by excessive power, while in a public company accounting fraud tends to be caused by performance stress. Hambrik and Mason (2004), proposes in the upperechelon theory that the role of a TMT (Top Management Team) is a crucial issue of company performance. Top Management Team (TMT) can be an elite team of the management, or can include one or more of the owners, or a majority share holder. Finkelstein and Hambrick (1984) found that the TMT has more power than the management. In other words, the TMT has strong influence on strategic implementation, operational decisions, or internal innovation processes. The TMT has such a power that it can create major fraud to benefit illegally at the cost of other stakeholders.

In case of BC, the role of TMT by dominant shareholder (Robert Tantular/RT) strongly influenced strategic decisions. Thus, to analyze the bank's internal problem by corporate governance and fraud, it is also important to analyze the role of the TMT.

The main question of this research is, considering all those facts; did the failure of $\mathrm{BC}$ have a systemic impact on the Indonesian banking system? Systemic means that it affects the entire organs of a banking industry. According to the government regulation about the Jaring Pengaman System Keuangan-Social Safety Net System (JPSK) or Peraturan Pemerintah Pengganti Undang-undangJaring Pengaman Stabilitaskeuangan (PERPPU JPSK), systemic impact is:

... a difficult condition caused by a bank, non bank financial institution, and/or financial market turbulence, which when it is not handled properly will cause failure to a number of banks and/or non bank financial institutions, and the people will lose trust into the financial system and the national economy.'

In PERPPU JPSK the criteria and size of a bank with systemic impact is not clearly defined. The nature of systemic impact can be internally or externally. Internally means the problem develops from inside a bank, such as nonprudential acts, while an external cause could be a natural disaster, a global financial crisis, or a war. Thus, in such cases it is difficult to demarcate the systemic impact of the bank. A financial institution can be systemic in certain situations, but not systemic in other situations. The indicator of systemic is also not mentioned explicitly in any law code, the reason is that it would cause moral hazards and that the criteria of systemic impact are situational depends on psychological market.

The Bank of Indonesia adopts the European Union Memorandum of Understanding (MOU) framework, which says that the consideration of a systemic impact has multiple aspects: financial system, financial market, payment system, real sector, and market psychological aspect. The market psychological aspect is added to the criteria in relation to the economic crisis in 1998. At that time, the closure of 16 banks, which had only $2.3 \%$ of the banking total assets, psychologically affected the financial market. It ended up with savings withdrawals in all national banks and caused a crisis in various sectors. Further, in the era of cyber dimension, cyber gossips (Wysocki, 1998) magnify the irrational behavior of investors through various rumors spreads in the internet.

Another important factor to consider in economic decision making is Risk. As Admati says (2013);

... When policymakers ignore risk, all of us may suffer in the end. A stark example was provided in Japan, where corrupted regulators and politicians colluded for years with the Tokyo Electric Power Company and ignored known safety concerns. When the earthquake and the tsunami happened in 2011, this neglect led to a nuclear disaster that was entirely preventable...'

Admati (2013) proposes that a banking system is not difficult to understand, that all issues will move quite straightforward if it is all purely a banking consideration, without any conflict of interest from the politicians. Admati (2013) also says that the banks 'are where the money is'. Money is the main goal and source of power. To control the money, bankers are in a strong position to influence the society together with politicians and government regulations. History shows that politicians have often used banks as money machines in political interests. The phenomena of politicians, regulators, and monetary authority having various interests in making a regulation for banking, are known as 'regulatory capture'. These actors create a Political Arena in the banking system. Together, they create a situation to achieve various interests while they are 'securing national financial stabilization'. As an example, the regulation of minimum percentage of reserve requirements tends to get higher during a financial crisis. Besides the noble purpose of securing the trustworthiness of the banks, this regulation gives a chance to the government to get free loans from the central bank, because the reserve requirement is indirectly financing the government. Even though the regulation captures are not always being negative, we also need to consider the grabbing hand or helping hand theory, which says that government intervention used to be laden in corrupted interests when the intervention has neither transparency nor accountability in the process (Hopkin and Pose, 2007). The regulators of banking industry should analyze three main layers to build a healthy intervention decision: market failure, corporate governance failure, and regulation failure of the Central Bank. 
This research does not discuss whether bank rush, nor capital flight, would happen if BC have been closed in 1998, but it approaches the problem of bailouts from multidisciplinary points of view: government-politics-economy. Seligman (1962: 345) proposes that the political factor needs to be related to economic and social changes in the society. Heilbroner (1977) proposes that if the economic science wants to keep relevant to modern problems, the science has to keep in pace with three areas of concern: political consideration need to be explicitly included in economic decisions, the political dimension needs to be broadened in economic decisions, and the knowledge needs a broader paradigm. Ilchman and Uphoff (1977) propose that economic decisions need to go through integrated social science of public purpose. In short, economic decision making needs to be approached multidisciplinary and to consider all relevant interests in social and political perspective.

\subsection{Methodology}

As a sample, this research takes BC, which operated from 2004 to 2008 along with its subsequent event data, supporting data from the Central Bank of Indonesia, depositor insurance's data, and all related data from various institutions in 2004-2008.

This research uses the time series method in an interpretative case study. The subjects are: executive officers of BC in 2004-2008, the owners of the bank Robert Tantular (RT) and Rafat Ali Rizvi (RAR), the former Vice President of the Republic of Indonesia (JusufKalla/JK), the former Government of Bank Indonesia (Budiono/BO), the former Ministry of Finance of the Republic of Indonesia (Sri Mulyani/SMI), special investigation team or Panitia Khusus (Pansus) Dewan Perwakilan Rakyat (DPR) of BC, Badan Reserse Kriminal (Bareskrim) Kepolisian Republik Indonesia, Badan Pemeriksa Keuangan (BPK) RI, officers of Lembaga Penjamin Simpanan (LPS), officers of Komisi Pemberantasan Korupsi (KPK), former officers ofBC and all related institutions. One ofthe researchers is ex-director of PT Bank CIC (one of the banks which formed the BC) from 1998 to 2001. Information are taken by interviews/letter/e-mail, in-depth analysis and direct observation from 2010 to 2014.Primary data are taken by interviewing former decision makers in the bailout and former officers of BC. The researchers interview the former Vice President of the Republic of Indonesia (JK) face to face and interview the former Government of Bank Indonesia (BO) by letter and email. Secondary data aretaken from the PT. Bank Century annual reports from 2004 to 2008, the investigation report of the Indonesian Central Bank, the audit report of BPK, the report of Pansus DPR of $\mathrm{BC}$ and all the supporting data. Investigation reports of Bareskrim, Press releases through television broadcast and newspaper reports are also analyzed to enrich the in-depth analysis.

Triangulation system does data observation. Primary data are grouped in peer debriefing. Secondary data are grouped and used to check consistency in subjects' opinions. Bias is minimized by triangular model based on the content analysis of primary and secondary data. Adjustment theory of before end theory and after end theory is also used to minimize bias

\subsection{Findings and discussion}

Considering internal problems of BC since 2005, was it worthy to be bailed out, and was the amount to bailout appropriate? Time series data of the financial report shows that foreign exchange securities, acceptance liability, and non performing loan made BC needs a very large amount of PPAP. Inability to meet the standard amount of PPAP made its CAR always fewer than 8\%. Detail calculation of CAR also shows that the appropriate amount to bail out was USD 5.7 Billions (Rp 5,724.541 million). Regarding the internal condition of BC it was not worthy to bail it out.

The financial report of $\mathrm{BC}$ shows that problems of corporate government and fraud in $\mathrm{BC}$ were very complex. It was not wise to bail it out as its default was not caused by financial crisis, but by weak governance, imprudent banking, and owner's fraud. Considering corporate governance theory, it was inappropriate to bail BC out. To bail BC out was to bail out any fraud caused by a dominant shareholder and his management, as if the bailout was to cater to certain party's interests. The important finding is that the amount to bail out was excessive and was used inappropriately. There were other interests rather than merely to keep the national banking stabile and to build banking trustworthiness during a global crisis. The decision of bailout shows that political interests have higher priority than other normative criteria.

Macro economically, the decision to bail out was taken to keep national banking stabile and to build banking trustworthiness during the global crisis. This is in accordance with Budiono (2008) who states that government intervention was needed to avoid a domino effect because of BC's bankruptcy. Darmin Nasution (2008) also states that government temporary equity was needed to rescue the bank. The bailout was very important to guarantee more than USD 6.7 Billions depository funds in the Indonesian banking system (Sri Mulyani, 2009). The government of Indonesia decided to settle the liquidity mismatch of this bank. Whether or not BC followed the regulation of the Indonesian Central Bank in accordance with basic rules of the Indonesian Banking Architecture 
was not being considered in the decision. Frauds that had happened inside the bank were given even broader scope by the big amount of money injected right into the bank. The decision to bailout was viewed in a macro politic context in the multi interests of the decision makers. There was a strong connection between political and economical factors. Failure to understand this big picture will create a narrow-minded financial or banking science. Based on field observations and interviews, the researchers conclude that there was a Grabbing Hand which indicates a relation with political aspects in the process of the bailout. The former owner of BC states that there was a powerful force behind the bailout (Robert Tantular, 2013)."The decisions makers understood that I would not have agreed to bail BC out so that I was not involved in the decision" (JK, 2009).Political interest of BC bailout can be mapped in the figure 1 below.

Was the decision to bail out relevant to national banking stabilization? The case of BC began with liquidity problems when a depositor wanted to draw back his money. BC could not pay its obligation because of its illiquid investment in non-rating, unmarketable securities while BC also did not keep its reserve requirement on the $12 \%$ level as it should have. The behavior finance theory was used when the government considered that the world was facing a global financial crisis and believed that if $\mathrm{BC}$ was closed, it would cause systemic impact. The government believed that closing any bank would have caused systemic domino effect and would have affected the government credibility. There was also rumor of negative market sentiments, and all the individual investors would have lost their trust in the banking system, and that would have caused chaos. This was dangerous for the national stability. The timing was very close to the presidential and legislative election in early 2009 . Considering the timing, to maintain national banking stability and trustworthiness mean maintain political stability. Inevitably the bailout was given to back up massive withdrawals.

Figure 01: Political interest, corporate governance, and fraud in the bail out Of BC

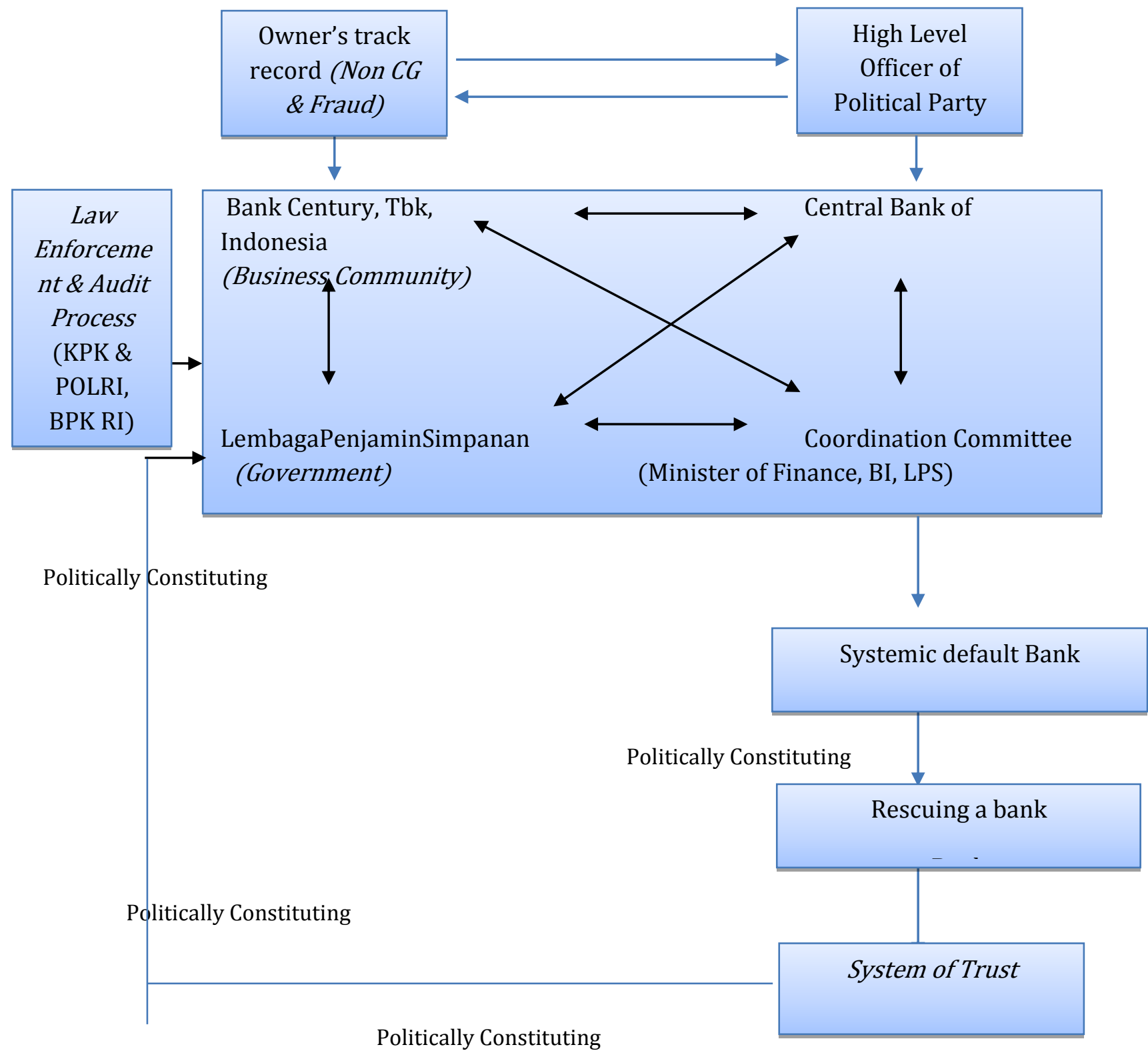


Explanation:

Politically Constituting : Politically causing an act or a decision

$\leftarrow \rightarrow$

: 'influencing each other

An election is a door to big change; it is wanted or unwanted by some actors because any major event would cause major shifts in the political arena. Consequently, many decisions will consider various interests of the actors. The decision to bail $\mathrm{BC}$ out was one of these decisions. The political, economic reason to bailout is that $\mathrm{BC}$ was 'too politically significant to fail'. The diagram can be seen in Picture 2 . As a matter of fact, the decision to bail out was able to maintain not only the national banking stability but also the stability of the political situation. The Indonesian economic indicators did improve after the government bailed $\mathrm{BC}$ out. Another fact was that the president at that time (Susilo Bambang Yudhoyono/SBY) was then re-elected to his second presidential term.

Picture 02: The economic and non-economic factors that politically constituting the bailout.

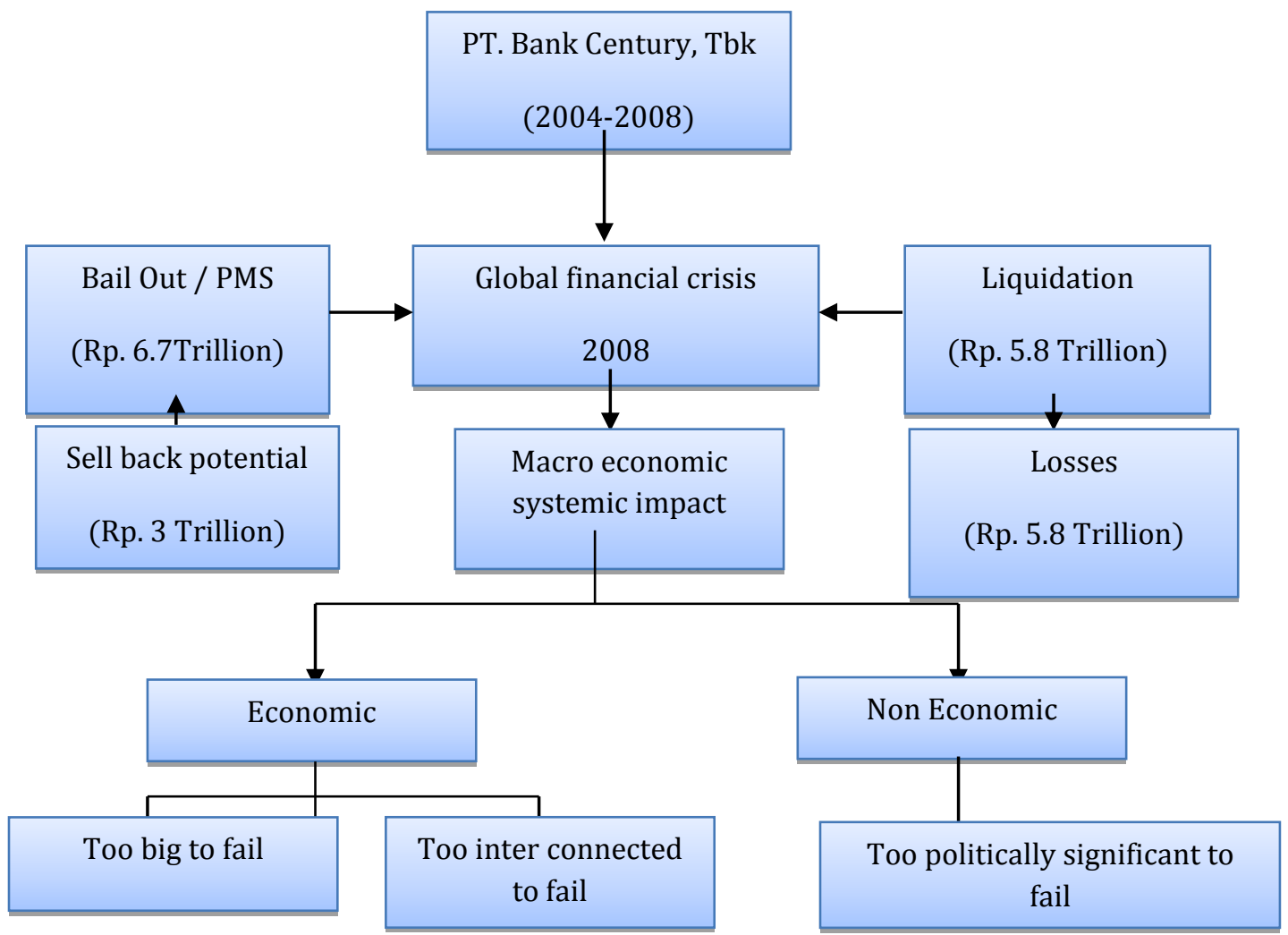

Source: Research findings, 2014 (Note: 1.00 USD = 11,868.75 IDR)

Was the failure of $\mathrm{BC}$ in 2008 a symptom of market failure, or a governance failure of $\mathrm{BC}$ and a regulation failure of the Indonesian Central Bank? Market failure was only a trigger to BC's default. The complicated frauds in BC made it failed to pay its obligations at the end of 2008. It was a failure to analyze banking system problems. Corporate governance failure was detected as a market failure, in turn, it caused a regulation failure. The Indonesian Central Bank failed to decide the right policy because there was some asymmetry information about BC's internal condition.

\subsection{Conclusion}

BC was a systematically risk bank, and it was bailed out because of noneconomic reasons. According to the theoretical observation and its implications, the bailout of $\mathrm{BC}$ was dominated by non-economical reasons. There was a financial global crisis, and the nation was on the verge of legislative and presidential elections. Regarding the benefit-loss analysis the bail-out of $\mathrm{BC}$ was aimed to stabilize the macro-economic and financial sector. In turn, this decision would prevent a domino effect of bank rush. The timing created a political, economic decision to bailout. This research defines it as 'too politically significant to fail'.

To rescue a bank, accountability and transparency in the cash management is needed. So it is better to avoid a cash bailout that tends to cause a conflict of interest. The bail-out technique is not appropriate to rescued $\mathrm{BC}$ from bankruptcy. A more effective tool is needed to rescue the bank. The researcher proposes a recapitulation procedure by obligation recapitulation as an additional working capital for the bank to avoid conflict of interest and political 
effects. This additional working capital could be obtained by overbooking depository premium funds of LPS in other banks, and transferred to the rescued bank either as loan or as time deposit. This alternative would have solved the liquidity problem, which means it would have been able to redeem market volatility. In turn this would have won back the banking system's trustworthiness. This alternative would have been more transparent and accountable because the depository premium funds of LPS would have been recorded in detail in the bank, and the fund would have gained some revenue of interest for the government. This alternative would also have avoided the polemic of a corrupted use of fund. This suggestion can be applied to guide the decision makers if they face a situation 'too politically significant to fail', ceteris paribus.

Finally, Future research needs to analyze the process of a bank takeover. Does the consideration of a negative track record of the shareholders influence the government to take it over? There was much conflict of interest in private banks, and this phenomenon keeps going on. The audit inspectors of BI are still having trouble with some owners of the bank. Future research also needs to investigate why bailouts mostly happen close to legislative/presidential election. Is there any other reason rather than an economic motive to rescue a bank?

\section{Reference}

Admati, Anat and Hellwig, Martin. 2013. The banker's new clothes: what's wrong with banking and what to do about it.Princeton University Press.

Akhtaruddin, M, Hossain, MA, Hossain, M \& Yao, L 2009.Corporate governance and voluntary disclosure in corporate annual reports of Malaysian listed firms. Journal of Applied Management Accounting Research, vol. 7, no. 1, pp. 1-19.

BadanPengawasKeuanganRepublik Indonesia.2008. Audit forum.http://www.bpk.go.id/webfiles/2009/01/Vol-xi-no.1 may2008/pdf.

Bank Indonesia, 2008.Metodeanalisis Bank indonesiamenetapkan Bank Century sebagai bank gagalberdampaksistemik.Jakarta, 2008.

Barzelay, Michael. 1993. The single case study as intellectually ambitious inquiry author(s) Journal of Public Administration Research and Theory. J-PART, Vol. 3, No. 3 (Jul., 1993), pp. 305318.http://www.jstor.org/stable/1181786diaksespada 3 January 2010.

Black, Fischer; Myron Scholes.1973.The pricing of options and corporate liabilities .Journal of Political Economy 81 (3): 637-654.

Boediono, 2009.Rapatpansus Bank Century di Dewan Perwakilan Rakyat Republik Indonesia tanggal 22 Desember 2009.Jakarta, 2009.

Burrel, Gibson and Gareth Morgan, 1979.Sociological paradigms and organizational analysis. Ashgate Publishing Limited, England.

Daniel, Kent and Sheridan Titman, 1997.Evidence on The Characteristics of Cross - Sectional Variance in Common Stock Returns. Journal of Finance, 52 (1): 1 - 33.

Daniel, Kent and Sheridan Titman, 1999.Market efficiency in an irrational world. Financial Analysis's Journal, 55 (6): $28-40$.

Davis, E.P. 1992. Debt, financial fragility and systemic risk. Oxford: Oxford University Press.

De Long,J. Bradford, Andrei Schleifer, Lawrence H. Summers and Robert J. Waldmann, 1990a. Noise trader risk and financial markets. Journal of Political Economy, 98 (4): 703 - 738.

Darmawati, D. dkk., 2004, Hubungan Corporate Governance dan Kinerja Keuangan, Simposium Nasional Akuntansi VII, Denpasar

Fama, Eugene F., (1970). Efficient capital market: a review of theory and empirical work. Journal of Finance, 25 (2): $383-417$.

Flannery, M. 1988. Payments system risk and public policy in W.S. Haraf and R.M. Kushmeider (eds) Restructuring Banking and Financial Services in America: 261-87. Washington, D.C.: American Enterprise Institute.

Friedman, Milton. 1953. The case for fllexible exchange rates, in essay in positive economics. Chicago: University of Chicago Press.

Gravitt, 2006. Recognizing financial statement fraud red flags. http://www.crowechizek.com/crowe/Publications/pdfs/RecognizingFinancialStateentFraud_PCS6203.pdf (accessed on 9 May 2007) Hamilton, S.,A. Micklethwait.2006.

Greenspan, Alan. 2001. Monetary policy report to the congress. before the committee on banking, Housing and $\begin{array}{lllll}\text { Urban } & \text { Affair } & \text { US } & \text { February } & 13,2001 .\end{array}$ http://www.federalreserve.gov/boarddoslhh/February/testimony/htm.

Grossman, Sanford Jay, Joseph E. Stiglit, 1980. On the impossibility of informational efficient markets.American Economic Reviews, 70 (3): 393 Herwidayatmo. 2000. Implementasgood corporate governance untukperusahaanpublik Indonesia. Artikelpada Majalah Usahawan No. 10 Th XXIX, Oktober 2000.

Hambrick, D. C., and P. A. Mason 1984.Upper echelons: The organization asareflection of its top managers. Academy of Management Review, 9: 193-206 
Hambrick, D.C. and S. Finkelstein.managerial discretion: a bridge between polar views of organizational fates, in research in organizational behavior, B. Staw and L.L. Cummings (eds.), JAI Press, 1987.

Heilbroner, Robert and Aaron Singer.The Economic Transformation of America. New York: Harcourt Brace Jovanovich, 1977.

Hopkin, Jonathan and Pose, Andres Rodriguez.2007. Grabbing hand or helping hand? Corruption and the economic role of the State.Governance: an International Journal of Policy, Administration and Institutions, Vol. 20, No. 2, April 2007 (pp. 187 - 208).

Ho, Simon S.M. dan Wong, Kar Shun. 2001. A study of relationship between corporate governance structure and extent of voluntary disclosure. Journal of International Accounting Auditing and Taxation, (10): 139-156.

Husnan, Suad., 2001. Corporate governance dankeputusanpendanaan: perbandingankinerjaperusahaandenganpemegangsahampengendaliperusahaanmultinasionaldanbukanmultin asional. Jurnal Riset Akuntansi, Manajemen, EkonomiVol. 1 No.1. Februari 2001:1-12

Iichman, F. Warren and Uphoff, Norman Thomas. 1977. The Political Economy of Change. Oxford University Press. International Accounting Standard. 2001. IFRS Foundation, Delaware.

Jensen, M.C. and Mecking, W., 1976. Theory of the firm: managerial behavior, agency costs and capital structure, Journal of Financial Economics, Vol. 3, pp: 305-360.

Jones, Charles, P., 2004. Investment, analysist and management. New Jersey: John Wiley and Sons.

Kaufman, George. G. 1996. Bank failures, systemic risk, and bank regulation.Cato Journal, Vol. 16, No. 1 (Spring/Summer 1996).

King, Robert G. and Levine, Ross.Financial intermediation and economic development, in financial intermediation in the construction of europe.Eds.: Colin Mayer and Xavier Vives. London: Centre for Economic Policy Research, 1993a, pp. 156-89.

Krugman, Paul. Maurice Obstfeld, Marc J. Melitz. 2007. International economics, theory and policy. Global Edition, Pearson.

Langevoort, Donald. C, 2002.Taming the animal spirits of the stock markets: a behavioral Approach to Securities Regulation.Berkeley program in law and economics.Working Paper, University of California Berkeley, 64.

Macey, J. R. \& O'Hara, M. 2003.The corporate governance of banks. Economic Policy Review 91-107.

Mark J. Flannery \&Sorin M. Sorescu, 1995.Pricing bank default risk in subordinated debenture yields,Proceedings 470, Federal Reserve Bank of Chicago.

Markowitz, Harry, 1952. Portfolio selection.Journal of Finance, 7 (1): 77 - 91.

Merton, Robert C. 1973. Theory of rational option pricing".Bell Journal of Economics and Management Science (The RAND Corporation) 4 (1): 141-183. doi:10.2307/3003143. JSTOR 3003143.[2]

Miller, Merton and Franco Modigliani, 1961.Dividen policy, growth and the valuation of shares, Journal of Business, 34 94): $411-433$.

Nasution, MarihotdanSetiawan, Doddy. 2007. Pengaruhcorporategovernanceterhadapmanajemenlaba di industriperbankan. Simposium Nasional Akuntansi X. Makassar. Ikatan Akuntanindonesia.

Nguyen, Khanh. 2008. Financial statement fraud: motives, methods, cases and detection. Florida. http://www.bookpump.com. Diaksestanggal 25 Oktober 2011.

Olsen, Robert, 1998. Behavioral finance and its implication for stock price volatility.Financial Analysts Journal, 54 (2): $10-18$.

Prasetyantoko, A., 2011.Momentum di tengahkrisis. HarianKompas, 19 September 2011, hal. 6.

Rubinstein, Mark., 2001. Rational market: yes or no? The affirmative case.Financial Analyst Journal, 57 (3): 15 - 29.

Seligman, R.A. Edwin. 1962. The economic interpretation of history. New York, Columbia University Press.

Sharpe William F., 1964.Capital asset pricing - a theory of market equilibrium under condition of Risk. Journal of Finance, 19 (3): 425 - 442.

Shleifer, Andre dan Lawrence Summers, 1990. The noise trader approach to finance, Journal of Economic Perspective, (4): 19 - 33.

Sheifer, Andre dan Robert Vishny, 1998. The grabbing hand, government pathologies and their cures. Cambridge, MA. Harvard University Press.

Shleifer, Andre and Robert Vishny, 1997.The limit of arbitrage. Journal of Finance,52, 35 - 55.

Shefrin, Hersh (2001). Beyond greed and fear; understanding behavioral finance and psychology of investing. Harvard Business School Press.

Skousen, C. And Wright, C. J. 2005.AAA 10th Ethic Research Symposium. Detecting financial statement fraud: an empirical assessment of thesis No. 99 fraud risk factors, American accounting association, ethic section, San Fransisco, California (August 6. 2005 - August 7. 2005).

Slovik, Patrick., 2012. Systematically important banks and capital regulation challenges. OECD Economics Department Working Papers, No. 916, OECD Publishing. http://dx.doi.org/10/1787/5kg0ps8cq8q6-en

Statement on Auditing Standards No. 99.Consideration of fraud in a financial statement audit. American Institute of Certified Public Accountant (AICPA), October 2002.

Statman, Meir., 1999. Behavioral finance; past battles and future engagements.Financial Analysts journal, 55 (6): 18 $-27$. 
Stiglitz, E. Joseph. Nobel price winner in economics globalization and it's discontents. 2003. WW Norton \& Company, New York - London.

SuadHusnan, 2001.Dasar-dasartteoriportfoliodananalisissekuritas, edisiKetiga, Yogyakarta: UPP AMP YKPN.

Supriyatno,2006, Pengaruh Corporate Governance danBentukKepemilikanterhadapKinerjaKeuangan Bank di Indonesia, Disertasi, UGM, Yogyakarta.

The Association of Certified Fraud Examiners.2012.http://www.acfe.com.

Tiscini, Riccardo and Donato, Fracesca di. 2004. The relation between accounting fraud and corporate governance systems: an analysis of recent scandals. http://ssrn.com/abstract=1086624.

Widoatmodjo, Sawidji. 2010. Mencarikebenaranobyektifdampaksistemik bank century. Penerbit PT. Elex Media Komputindo, Jakarta.

World Bank, 2009a. Crisis monitoring and response, using lot quality assurance sampling (LQAS), power point, 11 Mei, Jakarta: World Bank Poverty Team.

Wysocki, Peter. D. 1998. Cheap talk on the web: the determinants of posting on internet stock message boards. Working Paper, University of Michigan Business School.November.

Wysocki, Peter. D. 1999. Short seller and message posting activity on the web.Working Paper, University of Michigan Business School.October.

Wysocki, Peter. D. 2000. Private information, earnings announcements and trading volume.Working Paper, MIT, 29. Yin, Robert K. 2009.Cases study research: design and methods, fourth edition.Singapore, SAGE Publication.

\section{Appendix: Glossary}

BareskrimPolri (Badan Resersedan Kriminal Kepolisian Republik Indonesia) is the Institution under Head of Police Republic Indonesia that doing inspections and investigate the crime in the public.

BI (Bank Indonesia) is the Central Bank of republic Indonesia.

BPK RI (Badan Pemeriksa Keuangan Republik Indonesia) is the auditor that doing on behalf of the Government.

KPK (Komisi Pemberantasan Korupsi) is the Institutions in Indonesia that investigate the corruptions.

KSSK (Komite Stabilitas Sektor Keuangan) is the steering committee of Republic Indonesia had job for stability of macroeconomic and finance sector of the nations.

LPS (LembagaPenjaminSimpanan) is the Government Institutions in Indonesia that doing as guarantor of the savings and deposits in the banks up to the amount has appointed by Central Bank regulations.

PMS (Penyertaan Modal Sementara) is the bail-out of the bank by government or is like penetrant equity from the government to the private bank had acquired. 